\title{
Extending Shelf Life of Guava Fruits by Mint oil and UVC Treatments
}

\author{
Esameldin Bashir Mohamed Kabbashi*, Islam Kamal Saeed, Mawahib Yagoub Adam
}

\author{
National Food Research Center, Ministry of Higher Education \& Scientific Research, Sudan
}

\begin{abstract}
A lot of quarantine methods have been developed to replace fumigants in the control of arthropods and microorganisms in post-harvest management of fruits and vegetables. That is, guava fruit is infested in Sudan by a number of hexapods which include Ceratitis capitata Weid., Ceratitis quinaria (Bez.), Certatitis cosyra WLK., Bactrocera invadens Drew, Trusta \& White and Bactrocera zonata (Saunders).This study aims at using some uncommonly used treatments in improving the storability of guava fruits in Sudan. That is, UVC (ultraviolet rays type C) and coating with mint oil were used to disinfest guava from fruit flies at ambient temperature. The results, after 9 days bench storage, showed an infestation percentage of 20, 33 and $38 \%$ for mint, UVC and the control, respectively. The corresponding data for the range of infestation were 18, 20 and 48 and for the mean number of insects in infested fruits were 8.3, 8.8 and 15.2. The quality indexes studied reflected 9.5, 20.5 and $22.6 \%$ weight loss, for the mint oil, UVC and the control lots, respectively. The corresponding data for marketable retention (\%) were 100, 10 and 13; the fruit firmness, 1.6, 0.3, and 0.1; acidity (\%), 0.2 for all; ascorbic acid (mg/ $100 \mathrm{~g}$ pulp), 196, 190, and 194; reducing sugar (g/ $100 \mathrm{~g}), 8.2,7.6$, and 7.6; sensory quality includes appearance (\%), 84, 42, and 30; taste (\%), 79, 41, and 34; flavor (\%), 88, 42, and 40, respectively. These results revealed the edge of mint oil coating over UVC and the untreated lots.
\end{abstract}

Keywords-Guava, fruit flies, mint oil, UVC\& quality.

\section{INTRODUCTION}

Guava ( $P$. guajava) fruit is a lovable international dessert known by its rich nutritional and medicinal values (Kumar, 2012). It's one of the most popular fruits in the tropics and subtropics (Pathak etal., 2007) and in Sudan it's counted the fifth fruit in popularity (Ali etal, 2014). Guava production in Sudan is witnessed in rather all the states and in good amounts all the year round but this is faced with a lot of constraints related to transport, marketing, suitable storage and processing (Bushara etal., 2016). The fruit fly infestation has become a state of concern in Sudan since mid - 1970s when it was very severe and highly pushed the guava farmers to go out of production and some of them uprooted their trees in Shendi area (Bedri, 1978). This is followed by a continuous vigilance and thorough reports of the insect pests of guava fruit. That is about seven species were reported since 1960s which affected the production drastically besides highly reducing the export (Kabbashi, 2014).Roessler (1989) and Bateman (1982) described some management practices against fruit flies, such as getting rid of infested fruits; use of male attractants and lure; use of toxic baits, besides use of hot water dip for eggs and irradiation for male sterilization (Wood, 2000).A number of studies reflect good results of UV treatment in food (López-Rubira et al., 2005). That is, the postharvest quality of various crops was improved by exposure to low doses of UVC (Baka et al.1999; González-Aguilar et al., 2007; Stevens et al., 2004).The antimicrobial ability of short wave UVC (200-280 nm) is known as a potent treatment of water and as a disinfectant of package surface in the food processing(Bintsis et al., 2000; Keyser et al ., 2008; Koutchma et al., 2004). The cultivation of guava in Sudan is mainly by seed propagation which results in an uneven and diverse productivity. However, some attempts to improve such trend were taken by the Agricultural Research Corporation (ARC) by importing some cultivars in 1980s but not widely adopted throughout the country (Mahmoud etal., 1996). However, a recent work in the Sudanese guava genotypes recommends cultivating 13 out of 100 genotypes tested (Mahmoud and Peter, 2014). Additionally a number of technologies are available for shelf life extension and storage upgrading of horticultural commodities during the last decades, these include the use of anti transpirants (Chahal and Bal, 2003), wax coatings (Mahajan et al. 2005), growth retardants (Bisen and Pandey 2008), irradiation (Baghel et al. 2005) and other storage facilities that extend life of harvest fruits.

Guava fruit contains 5 times as much as the amount of vitamin $\mathrm{C}$ in orange besides oleanolic acid, flavonoids, guaijavarin, quercerlin and essential oils such as nerolidol, limonene and octanol. Its medicinal uses include antispasmodic, anti - inflammatory and antimicrobial effects. These besides its remedial uses against conjunctivitis, coughs, diabetes, malaria and 
rheumatism (Kumar, 2012).Vitamin $\mathrm{C}$ in guava was found $67.4 \%$ (Waziri and Salih, 2015). Guava also reported to have $5.1 \pm 0.85 \mathrm{mg} / 100 \mathrm{~g}$ lycopene which is known as a potent immunity helper and carcinogen suppresser (Nwaichi etal., 2015). However, a lot of literature speaks about the effectiveness of mint oil as a repellent for fruit flies. That is, pepper mint (Menthapiperita Willd.) oil proved a strong repelling effectiveness against all flies that attack a lot of fruits (Renkema etal., 2016). This oil also showed a high toxicity for the vine mealy bug [Planococcusficus (Signoret)] (Karamaouna et al., 2013).

This study aimed at evaluating two uncommonly used treatments (mint oil coating and UVC) to upgrade the quality of guava fruits in Sudan.

\section{MATERIALS AND METHODS}

\section{Materials:}

Guava fruits, fresh, good looking and uniform, from an orchard in Kadaro, North Khartoum. All of the fruits were of eating quality and were carefully selected to be identical in terms of shape, size, color, ripening stage, and with no blemishes or damage. The fruits were washed and graded according to uniform maturity. Ultra violet (C type, $254 \mathrm{~nm}$ ) light from a pharmacological company in Khartoum North (Shangahi - Sudan Co. Ltd); mint oil from the Department of Medicinal and Aromatic Plants of the National Center for Research, Khartoum.

\section{Methods:}

Guava fruits were randomly selected from an orchard in Kadaro (30 Km North Khartoum Center), any fruit showed a deviation (unfamiliar shape, blemishes, bruises, etc.) from normal was excluded. Three cartoons each had 15 pieces were subjected to $254 \mathrm{~nm}$ ultraviolet light type C (UVC light) for one hour. The test fruits were all thoroughly washed.The treated fruits were then stored for 9 days on bench at a laboratory of Postharvest Physiology Department of the National Food Research Center in Khartoum (the average temperature and average $\mathrm{RH}$ were $31^{\circ} \mathrm{C}$ and $21 \%$, respectively). The fruits were then dissected for fruit fly infestation after different storage periods assigned. The same experiment was done for the test of mint oil using a cotton wick to cover the fruit rind with. A corresponding control for each cartoon (15 fruits per cartoon) was used. Readings were taken after five days bench storage. However, fruit characteristics and chemical composition of the treated and untreated lots (at three days interval) were done at the Postharvest Physiology Department of the National food Research Center of the Ministry of Higher Education and Scientific Research, Khartoum.

The physiological weight loss (PWL), physico-chemical composition of fruits were taken after0, 3, 6 and the organoleptical value after 9 days of storage at ambient conditions. Flesh firmness was measured by the Magness and Taylor firmness tester plunger tip. Two readings were taken from opposite sides of each fruit after the peel was removed. The total soluble solids (TSS) of fruits were determined with the help of a hand refractometer of $0-32^{\circ}$ Brix range. The acidity, sugar and vitamin $\mathrm{C}$ contents were determined as per the method of AOAC (2002).The appearance, taste, and flavor of each sample were evaluated organoleptically by a panel of 10judges, giving scores out of ten.

\section{Statistical analysis:}

Analysis of variance (ANOVA), followed by Fisher's protected LSD test with a significance level of $\mathrm{P}<0.05$, were performed (Gomez and Gomez 1984).

\section{RESULTS AND DISCUSSION}

The readings of fruit flies in fruits treated with UVC; mint oil and the control are summarized in Tables 1, 2 and 3 , respectively. That is so because any infestation in a fruit may disqualify the whole lot for export and sometimes for local use. However, the statistical analysis of these results are summarized in Table 4 . That is, the mean of flies in infested fruits was 8.8, 8.3 and 15.24 for the mentioned three treatments, respectively; the mode of flies in infested fruits was $(3,7 \& 8), 3$, and 17 , respectively; the range of infestation was 20, 18 and 48, respectively; the infestation grand mode was 0,0 and 0 , respectively; the infestation grand mean was $2.93,1.67$ and 5.76, respectively, whereas the infestation percentage is $33.33,20$ and $38 \%$, for the UVC, mint oil and the untreated control, respectively. These results reflect clearly the advantage of using both treatments for the control of fruit flies in guava and the edge effect of mint oil over UVC.

Table.1: UVC (220 NM) for one hour Readings (fruit fly/ fruit)

\begin{tabular}{|l|l|l|l|l|l|l|l|l|l|l|l|l|l|l|l|}
\hline & \multicolumn{10}{l|}{ Fruit Flies per Fruit } \\
\hline Rep. & 1 & 2 & 3 & 4 & 5 & 6 & 7 & 8 & 9 & 10 & 11 & 12 & 13 & 14 & 15 \\
\hline Cartoon A & 9 & 0 & 0 & 0 & 0 & 0 & 0 & 0 & 0 & 7 & 7 & 0 & 0 & 0 & 0 \\
\hline Cartoon B & 0 & 8 & 0 & 4 & 18 & 0 & 0 & 6 & 0 & 0 & 0 & 8 & 15 & 1 & 21 \\
\hline Cartoon C & 0 & 0 & 0 & 0 & 5 & 0 & 0 & 0 & 0 & 0 & 3 & 0 & 3 & 0 & 17 \\
\hline
\end{tabular}


Table.2: Mint Readings (fruit fly/ fruit)

\begin{tabular}{|l|l|l|l|l|l|l|l|l|l|l|l|l|l|l|l|}
\hline & \multicolumn{11}{|c|}{ Fruit Flies per Fruit } \\
\hline Rep. & 1 & 2 & 3 & 4 & 5 & 6 & 7 & 8 & 9 & 10 & 11 & 12 & 13 & 14 & 15 \\
\hline Cartoon A & 0 & 0 & 0 & 0 & 0 & 0 & 0 & 0 & 0 & 0 & 0 & 0 & 3 & 2 & 0 \\
\hline Cartoon B & 0 & 0 & 0 & 0 & 0 & 0 & 0 & 0 & 0 & 20 & 6 & 5 & 3 & 9 & 10 \\
\hline Cartoon C & 0 & 0 & 0 & 0 & 0 & 0 & 0 & 0 & 0 & 0 & 0 & 0 & 0 & 25 dead & 17 \\
\hline
\end{tabular}

Table.3: Control Readings (fruit fly/ fruit)

\begin{tabular}{|l|l|l|l|l|l|l|l|l|l|l|l|l|l|l|l|}
\hline & \multicolumn{10}{|l|}{ Fruit Flies per Fruit } \\
\hline Rep. & 1 & 2 & 3 & 4 & 5 & 6 & 7 & 8 & 9 & 10 & 11 & 12 & 13 & 14 & 15 \\
\hline Cartoon A & 0 & 0 & 0 & 0 & 0 & 0 & 0 & 0 & 0 & 0 & 0 & 17 & 49 & 8 & 36 \\
\hline Cartoon B & 0 & 0 & 0 & 0 & 0 & 0 & 11 & 5 & 17 & 0 & 0 & 13 & 19 & 17 & 0 \\
\hline Cartoon C & 6 & 0 & 0 & 0 & 0 & 0 & 0 & 5 & 0 & 0 & 1 & 24 & 12 & 11 & 8 \\
\hline
\end{tabular}

Table.4: Test Statistical Analysis for Infestation

\begin{tabular}{|l|l|l|l|}
\hline \multirow{2}{*}{ Parameter } & Fruit Flies & Mint Oil \\
\cline { 2 - 4 } & Control & UVC & 8.3 \\
\hline Mean of flies in infested fruits & 15.24 & 8.8 & 3 \\
\hline Mode of flies in infested fruits & 17 & $3,7 \& 8$ & 18 \\
\hline Range of infestation & 48 & 20 & 0 \\
\hline Grand Mode of flies in test fruits & 0 & 0 & 1.67 \\
\hline Grand Mean of flies in infested fruits & 5.76 & 2.93 & 20 \\
\hline Infestation Percentage & 37.78 & 33.33 & \\
\hline
\end{tabular}

\section{Effect of UVC on Hexapods and Fruit Flies:}

Irradiation with short wave length UVC was found killing to immature stages of Drosophilamelanogaster (Hori etal., 2014). The effect of UVC light (254 nm) on two Tribolium species (castaneum and confusum) and Cardacautella reflected that all the species eggs hatch was inversely proportional with the exposure and a 24 minutes period exposure effected zero hatchability in 2 and 3 days old Triboliumcastaneum eggs. In addition the adult emergence was significantly affected according to the radiation duration which yielded $100 \%$ in 2 and 3 days old T.confusum eggs exposed for $16-24$ minutes (Faruki etal., 2007). The detrimental ability of UV light was reported in Drosophilamelanogaster which suffered eye damage when exposed to intense UV light (Stark etal., 1985). It was also reported that the UV light toxicity differs with insect species (Hori etal, 2014). The ovicidal effect of UVC was reported to reach total mortality for a dose $1.384 \mathrm{kJm}^{-2}$ or higher (Viera etal., 2009). However, the eggs of mango fruit fly (C.cosyra) and the invader fly (B. invadens) were found far more resistant to gamma irradiation than the other developmental stages (Kabbashi etal, 2012). This information supports the findings found in this study about UVC irradiation of guava for disinfestation from fruit flies. However, this treatment inspite of being not a choice for disinfesting guava from fruit flies yet it can be considered as a component of an integrated management program.

\section{Effect of mint oil on store product insects:}

Mint belongs to the family Lamiaceae (Labiatae) which include members with oils that have potency against insect pests. That is, the $\mathrm{LC}_{50}$ and $\mathrm{LC}_{90}$, in order, for $T$. castaneum adults were found 46.8 and $584.3 \mu \mathrm{l} / 1$ (ppm) (Rastegar etal., 2009). The toxicity of some mint species was studied against the house fly (MuscadomesticaL.). That is, a dose of $225 \mathrm{ppm}\left(\mathrm{LC}_{50}\right)$ and $270 \mathrm{ppm}\left(\mathrm{LC}_{75}\right)$ were reported for pepper mint (Menthapiperita L.) (Bosly, 2013). In addition mint (Mentha spp.) essential oils werereported to have insecticidal activity against the different developmental stages of a number of store insects (Rajendran and Sriranjini, 2008; Kumar etal., 2010 \& 2011; Michaelakis etal., 2012). However, the effectiveness of piper mint (M. piperita) essential oils was found distinct among other five tested plant extract considering their insect killing ability (Kumar etal., 2011). M. viridis analysis revealed its constituents to be dominated by carvone while other components include limonene, terpinen and 1, 8 - cinole(Mkaddem etal., 2009). Oil of Menthalongifolia L. was found to be mainly composed of pulegone $(75 \%)$ and other minor constituents that include 1,8-cineole, L. menthone and eucarvone. However, its $\mathrm{LC}_{50}$ against cowpea beetle [Callobruchusmasculatus (F.)] was reported as 4.43 ppm 
which exhibited anticholinesterase activity at $\mathrm{LC}_{50} 1.01$ ppm (Al - Sarar etal., 2014). Spear mint [M. viridis (spicata)] at concentration higher than $0.5 \%$ produced total kill in Oryzaephilussurinamensis (L.) (Al - Jabr, 2006). These studies reflect the killing ability of mint species against an array of insect species which support the findings in this study.

The analyses of the treated and untreated guava fruits (Tables 5-8) reflect the success of UVC and mint oil coating treatments in extending the quality life of guava fruits. That is, the study parameters include physical characteristics, total soluble solids (TSS), chemical composition and sensory evaluation. However, the coating with oil mint is superior to UVC treatment according to the findings of this study.

\subsection{Effect on weight loss:}

Weight loss progressively increased during storage of guava fruits regardless of treatment. Weight loss was followed until the fruits reached the full yellow stage. The control fruits, reached the highest weight loss percentage of $25.2 \%$ after 4 days (Table 5). The lowest physiological weight loss of $0,1.4,7.0$ and $9.5 \%$ after 0 , 3,6 and 9 days of storage, respectively, were recorded in guava fruits coated with mint oil which were found significantly superior and followed by UVC treatment (Table 5). Mint coating closed the opening of stomata and lenticels thereby, reducing the transpiration and respiration rates and reduced the microbial activity. Multiple oil coating keeps the

fruit value and lessen the ethylene production in pineapple which lead to a lesser weight loss (Thomas etal. 2005). Comparable work in guava was also available (Jagadeesh etal., 2001). This fact elucidate the effect of mint oil on guava fruits concerning the weight loss parameter. However, on the contrary the energy generated from the UVC treatment may account for an additional difference in weight loss compared to the other treated lot.

\subsection{Marketable (Shelf life) period:}

Data tabulated in Table (5) showed that the longest marketable period was obtained with fruits treated by mint oil coating i.e. all marketable fruits were retained in $100 \%$ marketable condition after $0,3,6$ and 9 days of storage.The results of the other test fruits are far less compared to the mint treated fruits throughout the storage period. The reason for the extension in shelf life in mint oil treated fruits is attributed to the reduced rate of water loss and lesser availability of oxygen that lead to a slowdownin the rate of ripening of fruits as well as in color change. Similar findings were reported in guava (Singh and Shaffat, 1997), kinnow fruits (Mahajan etal., 2005) andin mango fruits (Dhemre and Waskar, 2003).

Table.5: Effect of UVC radiation and mint oil coating on the physical parameters of guava fruits

\begin{tabular}{|c|c|c|c|c|c|c|c|c|}
\hline \multirow[t]{2}{*}{ Treatment } & \multicolumn{4}{|c|}{ Physiological Loss (\%) } & \multicolumn{4}{|c|}{ Marketable fruit retained $*(\%)$} \\
\hline & 0D & $3 \mathrm{D}$ & $6 \mathrm{D}$ & 9D & OD & $3 \mathrm{D}$ & $6 \mathrm{D}$ & 9D \\
\hline Control & $\begin{array}{l}0.00^{\mathrm{j}} \\
\pm 0.0\end{array}$ & $\begin{array}{l}10.30^{\mathrm{e}} \\
\pm 0.15\end{array}$ & $\begin{array}{l}25.20^{\mathrm{a}} \\
\pm 0.32\end{array}$ & $\begin{array}{l}22.60^{\mathrm{b}} \\
\pm 0.28\end{array}$ & $\begin{array}{l}100.00^{\mathrm{a}} \\
\pm 0.0\end{array}$ & $\begin{array}{l}86.00^{\mathrm{b}} \\
\pm 0.26\end{array}$ & $\begin{array}{l}53.40^{\mathrm{d}} \\
\pm 0.19\end{array}$ & $\begin{array}{l}13.00^{\mathrm{f}} \\
\pm 0.07\end{array}$ \\
\hline Mint oil & $\begin{array}{l}0.00^{\mathrm{j}} \\
\pm 0.0\end{array}$ & $\begin{array}{l}1.40^{\mathrm{i}} \\
\pm 0.09\end{array}$ & $\begin{array}{l}7.00^{\mathrm{g}} \\
\pm 0.08\end{array}$ & $\begin{array}{l}9.50^{f} \\
\pm 0.11\end{array}$ & $\begin{array}{l}100.00^{\mathrm{a}} \\
\pm 0.00\end{array}$ & $\begin{array}{l}100.00^{\mathrm{a}} \\
\pm 0.00\end{array}$ & $\begin{array}{l}100.00^{\mathrm{a}} \\
\pm 0.00\end{array}$ & $\begin{array}{l}100.00^{\mathrm{a}} \\
\pm 0.00\end{array}$ \\
\hline $\begin{array}{l}\text { UVC } \\
\text { radiation }\end{array}$ & $\begin{array}{l}0.00^{\mathrm{j}} \\
\pm 0.0\end{array}$ & $\begin{array}{l}5.20^{\mathrm{h}} \\
\pm 0.07\end{array}$ & $\begin{array}{l}12.30^{\mathrm{d}} \\
\pm 0.18\end{array}$ & $\begin{array}{l}20.50^{\mathrm{c}} \\
\pm 0.24\end{array}$ & $\begin{array}{l}100.00^{\mathrm{a}} \\
\pm 0.0\end{array}$ & $\begin{array}{l}80.70^{c} \\
\pm 0.21\end{array}$ & $\begin{array}{l}40.00^{\mathrm{e}} \\
\pm 0.13\end{array}$ & $\begin{array}{l}10.00^{\mathrm{g}} \\
\pm 0.05\end{array}$ \\
\hline $\mathrm{LSD}_{0.05}$ & \multicolumn{4}{|c|}{$0.5055^{* *}$} & \multicolumn{4}{|l|}{$1.54 * *$} \\
\hline $\mathrm{SE} \pm$ & \multicolumn{4}{|c|}{0.1732} & \multicolumn{4}{|l|}{0.5276} \\
\hline
\end{tabular}

Values are mean \pm SD.

Mean value(s) bearing different superscript(s) are significantly different $(\mathrm{P} \leq 0.05)$.

\subsection{Effect on total soluble solids:}

The TSS of fruits gradually increased up to 6 days in all treatments and decreased after that irrespective of treatments (Table 6). The maximum (17.6\%) TSS was recorded in mint oil coating followed by UV radiation (16.4\%) whichwas found also significantly superior to control (14.8\%) after 6 days of storage.This corroborates earlier findings that the physico - chemical parameters increase up to 8 days in guava fruits under storage (Chandra, 1995). That is, the drop in TSS in this study was observed after 9 days storage (Table, 6). Heedless, the increase in TSS up to 8 days,in stored guava, may be referred to the decomposition of acids and accumulation of polysaccharides during storage. Additionally, increase in TSS due to coating was reported in pineapple fruits (Das and Medhi, 1990). 
Table.6: Effect of UV radiation and mint oil coating on total soluble solid and flesh firmness of guava fruits

\begin{tabular}{|c|c|c|c|c|c|c|c|c|}
\hline \multirow[t]{2}{*}{ Treatment } & \multicolumn{4}{|c|}{ TSS (\%) } & \multicolumn{4}{|c|}{ Flesh Firmness* $\left(\mathrm{kg} / \mathrm{cm}^{2}\right)$} \\
\hline & OD & $3 \mathrm{D}$ & $6 \mathrm{D}$ & 9D & OD & $3 \mathrm{D}$ & $6 \mathrm{D}$ & $9 \mathrm{D}$ \\
\hline \multirow[t]{2}{*}{ Control } & $12.00^{\mathrm{f}}$ & $14.20^{\mathrm{de}}$ & $14.80^{\mathrm{cd}}$ & $13.50^{\mathrm{e}}$ & $2.30^{\mathrm{a}}$ & $1.20^{\mathrm{d}}$ & $0.25^{\mathrm{f}}$ & $0.10^{\mathrm{g}}$ \\
\hline & \pm 0.00 & \pm 0.13 & \pm 0.16 & \pm 0.07 & \pm 0.00 & \pm 0.01 & \pm 0.01 & \pm 0.01 \\
\hline \multirow[t]{2}{*}{ Mint oil } & $12.00^{\mathrm{f}}$ & $16.30^{\mathrm{b}}$ & $17.60^{\mathrm{a}}$ & $16.20^{\mathrm{b}}$ & $2.30^{\mathrm{a}}$ & $2.30^{\mathrm{a}}$ & $1.75^{\mathrm{b}}$ & $1.55^{\mathrm{c}}$ \\
\hline & \pm 0.00 & \pm 0.25 & \pm 0.28 & \pm 0.23 & \pm 0.00 & \pm 0.00 & \pm 0.04 & \pm 0.03 \\
\hline UVC & $12.00^{\mathrm{f}}$ & $15.20^{\mathrm{c}}$ & $16.40^{\mathrm{b}}$ & $15.10^{\mathrm{c}}$ & $2.30^{\mathrm{a}}$ & $0.75^{\mathrm{e}}$ & $0.30^{f}$ & $0.25^{f}$ \\
\hline radiation & \pm 0.00 & \pm 0.21 & \pm 0.26 & \pm 0.18 & \pm 0.00 & \pm 0.01 & \pm 0.01 & \pm 0.01 \\
\hline $\mathrm{LSD}_{0.05}$ & \multicolumn{4}{|c|}{$0.8543^{* *}$} & \multicolumn{4}{|l|}{$0.1305^{*}$} \\
\hline $\mathrm{SE} \pm$ & \multicolumn{4}{|l|}{0.2927} & \multicolumn{4}{|l|}{0.0447} \\
\hline
\end{tabular}

Values are mean \pm SD.

Mean value(s) bearing different superscript(s) are significantly different $(\mathrm{P} \leq 0.05)$.

\subsection{Effect on flesh firmness:}

Fruit flesh firmness progressively declined during the storage of guava fruits. Pectin was found the polymer of the firmness in guava fruits. That is, a continuous decrease in this polymer in the cell wall accompanied by its accumulation in the center of the cell was assessed in guava fruit during storage using ruthenium red (De Abreu etal., 2012). Mint oil coating significantly delayed the drop in fleshfirmness during the storage of guava fruits and retained maximum texture (67\%) up to 9 days of storage, the corresponding results for UVC treated lots and the untreated control were $11 \%$ and $4 \%$, respectively (Table 6). The edible oil coatings preserve the quality of fruits, retard ethylene emission and enhance texture(Lin and Zhao, 2007). These results validate the findings of Dashora etal. (1999). The UVC treated fruits showed a decline in firmness, and reached the final soft stage $\left(0.25 \mathrm{~kg} / \mathrm{cm}^{2}\right)$ after 9 days storage which is far better compared to the control that reflected a corresponding figure of 0.1 (Table 6). Similar drop in guava fruits have been reported [Bashir and $\mathrm{Abu}-$ Goukh (2002) and Abu - Goukh andAbu - Sarra,
(1993)].The energy generated from the UVC treatment may account for the more reduction in firmness as compared to the other test lots. However, it is worth reporting that the difference between the readings is significant at 5\% level [Table 6 (figures bear different letters)].

\subsection{Titratable acidity:}

Titratable acidity of guava fruits increased up to the climacteric peak and declined

thereaftertill the end of the storage period ( 9 days). This as in the fruits of the untreated control. However, the TA increased with time throughout the storage period in the treated lots by both mint oil and the UVC (Table 7). This infers the effect of these treatments in extending the climacteric period, perhaps. Similar results were reported duringripening of banana (Ahmed and Tingwa, 1975; Desai \& Deshpande, 1978) and mango (Abu Goukh and Abu -Sarra, 1993).This sizable decrease in TA could be attributed to its use as a substrate for respiration. Coated fruits, showed the higher flesh acid content value(Table 7).

Table.7: Effect of UV radiation and mint oil coating on the chemical parameters of guava fruits

\begin{tabular}{|c|c|c|c|c|c|c|c|c|c|c|c|c|}
\hline \multirow{2}{*}{$\begin{array}{c}\text { Treatme } \\
\text { nt }\end{array}$} & \multicolumn{4}{|c|}{ Acidity (\%) } & \multicolumn{4}{|c|}{ Ascorbic Acid * $(\%)$} & \multicolumn{4}{|c|}{ Reducing sugars $(\%)$} \\
\hline & OD & $3 \mathrm{D}$ & $6 \mathrm{D}$ & 9D & OD & $3 \mathrm{D}$ & $6 \mathrm{D}$ & $9 \mathrm{D}$ & OD & $3 \mathrm{D}$ & $6 \mathrm{D}$ & 9D \\
\hline Control & $\begin{array}{l}0.170^{\mathrm{a}} \\
\pm 0.00\end{array}$ & $\begin{array}{l}0.174 \\
\text { a } \\
\pm 0.03\end{array}$ & $\begin{array}{l}0.200^{\mathrm{a}} \\
\pm 0.02\end{array}$ & $\begin{array}{l}0.193^{\mathrm{a}} \\
\pm 0.01\end{array}$ & $\begin{array}{c}170.00 \\
\text { i } \\
\pm 0.00\end{array}$ & $\begin{array}{c}188.00 \\
\mathrm{~h} \\
\pm 0.65\end{array}$ & $\begin{array}{l}197.0 \\
\pm 0.76\end{array}$ & $\begin{array}{c}190.00^{\mathrm{g}} \\
\pm 0.71\end{array}$ & $\begin{array}{l}5.90^{\mathrm{i}} \\
\pm 0.00\end{array}$ & $\begin{array}{r}6.11^{\mathrm{g}} \\
\pm 0.03\end{array}$ & $\begin{array}{l}6.80^{\mathrm{e}} \\
\pm 0.09\end{array}$ & $\begin{array}{l}7.60^{\mathrm{b}} \\
\pm 0.16\end{array}$ \\
\hline Mint oil & $\begin{array}{l}0.170^{\mathrm{a}} \\
\pm 0.00\end{array}$ & $\begin{array}{l}0.177^{\mathrm{a}} \\
\pm 0.01\end{array}$ & $\begin{array}{l}0.190^{\mathrm{a}} \\
\pm 0.01\end{array}$ & $\begin{array}{l}0.210^{\mathrm{a}} \\
\pm 0.02\end{array}$ & $\begin{array}{c}170.00 \\
\text { i } \\
\pm 0.00\end{array}$ & $\begin{array}{c}199.00 \\
\quad c \\
\pm 0.81\end{array}$ & $\begin{array}{c}204.00 \\
\quad \text { a } \\
\pm 0.87\end{array}$ & $\begin{array}{c}196.00^{\mathrm{e}} \\
\pm 0.74\end{array}$ & $\begin{array}{c}5.90^{\mathrm{i}} \\
\pm 0.00\end{array}$ & $\begin{array}{l}6.10^{\mathrm{h}} \\
\pm 0.01\end{array}$ & $\begin{array}{r}7.45^{\mathrm{c}} \\
\pm 0.15\end{array}$ & $\begin{array}{l}8.20^{\mathrm{a}} \\
\pm 0.19\end{array}$ \\
\hline $\begin{array}{c}\text { UVC } \\
\text { radiation }\end{array}$ & $\begin{array}{c}0.170^{\mathrm{a}} \\
\pm 0.00\end{array}$ & $\begin{array}{l}0.175^{\mathrm{a}} \\
\pm 0.01\end{array}$ & $\begin{array}{c}0.180^{\mathrm{a}} \\
\pm 0.00\end{array}$ & $\begin{array}{l}0.200^{\mathrm{a}} \\
\pm 0.02\end{array}$ & $\begin{array}{c}170.00 \\
\text { i } \\
\pm 0.00\end{array}$ & $\begin{array}{c}198.30 \\
c \\
\pm 0.79\end{array}$ & $\begin{array}{c}201.70 \\
\text { b } \\
\pm 0.85\end{array}$ & $\begin{array}{c}194.00^{\mathrm{f}} \\
\pm 0.72\end{array}$ & $\begin{array}{c}5.90^{\mathrm{i}} \\
\pm 0.00\end{array}$ & $\begin{array}{c}6.15^{f} \\
\pm 0.04\end{array}$ & $\begin{array}{l}6.85^{\mathrm{d}} \\
\pm 0.11\end{array}$ & $\begin{array}{c}7.60^{b} \\
\pm 0.16\end{array}$ \\
\hline $\mathrm{LSD}_{0.05}$ & \multicolumn{4}{|c|}{$0.4706^{*}$} & \multicolumn{4}{|c|}{$1.54 * *$} & \multicolumn{4}{|c|}{$0.0005^{*}$} \\
\hline $\mathrm{SE} \pm$ & \multicolumn{4}{|c|}{0.1612} & \multicolumn{4}{|c|}{0.5276} & \multicolumn{4}{|c|}{0.0002} \\
\hline
\end{tabular}

Values are mean \pm SD.

Mean value(s) bearing different superscript(s) are significantly different $(\mathrm{P} \leq 0.05)$ 


\subsection{Effect on ascorbic acid content:}

Vitamin $\mathrm{C}$ content of fruits irrespective of treatments increased up to 6 days storage and then declined on day 9 of storage (Table 7). Coated fruits with (mint oil) recorded the highest $(204 \mathrm{mg} / 100 \mathrm{~g}$ after 6 days storage) throughout the test period( 9 days storage) and was found significantly superior to all other treatments. The increase in vitamin $\mathrm{C}$ content in earlier stages of storage may be due to the increasing rate of phenol production whereas, during storage (after 6days), the increase may be due to conversion of L-ascorbic acid into dehydroascorbic acid. Similar results have also been stated in earlier study in guava fruits (Mahajan et al., 2005).

\subsection{Reducing Sugars:}

The reducing sugars in the guava fruits increased up to the climacteric peak and subsequently decreased. Maximum value reached was 8 ( $\mathrm{g} / 100 \mathrm{~g}$ fresh weight) (Table 7). Climacteric fruits, in particular, may show considerable change in sugar content during fruit ripening (Hulme, 1970). Starch and sucrose change into glucose during fruit ripening (Wills et al, 1981).Increasing trend of reducing sugars of fruits was observed (Table 7) up to 6 days of storageand then decreased in all test fruits except mint oil the reducing sugars decreased and then increased. This may be due to a rapid conservation of polysaccharides into sugars in the earlier stage and later to utilization of sugars in respiration. These findings are in line with what was found in custard apple (El- Monem et al., 2003). Mint oil coating recorded the highest reducing sugars $(8.2 \mathrm{~g} / 100$ g) after 9 days storage and was found significantly superior to all other treatments.

\subsection{Sensory quality:}

Maximum acceptability in terms of taste was retained by mint oil coating without any objectionable change up to 9 days of storage followed by UVC treatment (Table 8). Edible oil coating retained good value of taste due to retention of appreciable amount of sugar and a proper TSS/acid ratio up to 9 days of storage. During storage taste scores decreased. Maximum (84\%) appearance of fruits was retained undercoating with mint oil after 9 days of storage followed by UVC treatment. This corroborates similar findings in mango fruits(Dhaka etal., 2001). Flavor of fruits increased with ripening of fruits and attained its peak at 6 days of storage. Thereafter, during storage up to 9 days, the flavour score decreased. The highest value of $60,75,91$ and $88 \%$ for flavour was recorded under mint oil coating at 0,3,6 and 9 days of storage, respectively. The flavour increased due to enhancement in the chemical attributes of fruits like increase in sugars and TSS/acid ratio where, it decreased at 9 days of storage due to degradative metabolism (Table 8).

Table.8: Effect of UVC radiation and mint oil coating on the sensory scores of guavafruits

\begin{tabular}{|c|c|c|c|c|c|c|c|c|c|c|c|c|}
\hline \multirow[t]{2}{*}{ Treatment } & \multicolumn{4}{|c|}{ Appearance (\%) } & \multicolumn{4}{|c|}{ Taste (\%) } & \multicolumn{4}{|c|}{ flavor $(\%)$} \\
\hline & OD & $3 \mathrm{D}$ & $6 \mathrm{D}$ & 9D & OD & $3 \mathrm{D}$ & $6 \mathrm{D}$ & 9D & OD & $3 \mathrm{D}$ & $6 \mathrm{D}$ & 9D \\
\hline Control & $\begin{array}{c}100.0 \\
0^{\mathrm{a}} \\
\pm 0.00\end{array}$ & $\begin{array}{c}85.0 \\
0^{\mathrm{e}} \\
\pm 0.5 \\
5\end{array}$ & $\begin{array}{c}49.0 \\
0^{\mathrm{g}} \\
\pm 0.3 \\
9\end{array}$ & $\begin{array}{c}30.0 \\
0^{\mathrm{i}} \\
\pm 0.2 \\
2\end{array}$ & $\begin{array}{l}60.00^{\mathrm{g}} \\
\pm 0.00\end{array}$ & $\begin{array}{l}71.00^{\mathrm{f}} \\
\pm 0.43\end{array}$ & $\begin{array}{l}45.00^{\mathrm{h}} \\
\pm 0.36\end{array}$ & $\begin{array}{l}34.00^{j} \\
\pm 0.26\end{array}$ & $\begin{array}{c}60.0 \\
0^{\mathrm{g}} \\
\pm 0.0 \\
0\end{array}$ & $\begin{array}{c}74.0 \\
0^{\mathrm{d}} \\
\pm 0.4 \\
8\end{array}$ & $\begin{array}{c}65.0 \\
0^{\mathrm{e}} \\
\pm 0.4 \\
7\end{array}$ & $\begin{array}{c}40.00 \\
\mathrm{~h} \\
\pm 0.31\end{array}$ \\
\hline Mint oil & $\begin{array}{c}100.0 \\
0^{\mathrm{a}} \\
\pm 0.00\end{array}$ & $\begin{array}{c}97.0 \\
0^{\mathrm{b}} \\
\pm 0.6 \\
1\end{array}$ & $\begin{array}{c}93.0 \\
0^{\mathrm{c}} \\
\pm 0.5 \\
9\end{array}$ & $\begin{array}{c}84.0 \\
0^{\mathrm{e}} \\
\pm 0.5 \\
4\end{array}$ & $\begin{array}{l}60.00^{\mathrm{g}} \\
\pm 0.00\end{array}$ & $\begin{array}{l}91.00^{\mathrm{b}} \\
\pm 0.58\end{array}$ & $\begin{array}{l}96.00^{\mathrm{a}} \\
\pm 0.63\end{array}$ & $\begin{array}{l}79.00^{\mathrm{d}} \\
\pm 0.51\end{array}$ & $\begin{array}{c}60.0 \\
0^{\mathrm{g}} \\
\pm 0.0 \\
0\end{array}$ & $\begin{array}{c}75.0 \\
0^{\mathrm{d}} \\
\pm 0.4 \\
9\end{array}$ & $\begin{array}{c}91.0 \\
0^{\mathrm{a}} \\
\pm 0.5 \\
8\end{array}$ & $\begin{array}{c}88.00 \\
\text { b } \\
\pm 0.54\end{array}$ \\
\hline $\begin{array}{c}\text { UVC } \\
\text { radiation }\end{array}$ & $\begin{array}{c}100.0 \\
0^{\mathrm{a}} \\
\pm 0.00\end{array}$ & $\begin{array}{c}89.0 \\
0^{\mathrm{d}} \\
\pm 0.5 \\
6\end{array}$ & $\begin{array}{c}79.0 \\
0^{\mathrm{f}} \\
\pm 0.5 \\
3\end{array}$ & $\begin{array}{c}42.0 \\
0^{\mathrm{h}} \\
\pm 0.3 \\
4\end{array}$ & $\begin{array}{l}60.00^{\mathrm{g}} \\
\pm 0.00\end{array}$ & $\begin{array}{l}87.00^{c} \\
\pm 0.55\end{array}$ & $\begin{array}{l}73.00^{\mathrm{e}} \\
\pm 0.46\end{array}$ & $\begin{array}{l}41.00^{\mathrm{i}} \\
\pm 0.32\end{array}$ & $\begin{array}{c}60.0 \\
0^{\mathrm{g}} \\
\pm 0.0 \\
0\end{array}$ & $\begin{array}{c}75.0 \\
0^{\mathrm{d}} \\
\pm 0.4 \\
9\end{array}$ & $\begin{array}{c}83.0 \\
0^{c} \\
\pm 0.5 \\
2\end{array}$ & $\begin{array}{c}42.00 \\
\mathrm{~g} \\
\pm 0.33\end{array}$ \\
\hline $\mathrm{LSD}_{0.05}$ & \multicolumn{4}{|c|}{1.685} & \multicolumn{4}{|c|}{1.685} & \multicolumn{4}{|c|}{1.685} \\
\hline $\mathrm{SE} \pm$ & \multicolumn{4}{|c|}{0.5774} & \multicolumn{4}{|c|}{0.5774} & \multicolumn{4}{|c|}{0.5774} \\
\hline
\end{tabular}

Values are mean \pm SD

Mean value(s) bearing different superscript(s) are significantly different $(\mathrm{P} \leq 0.05)$

\section{REFERENCES}

[1] Abu- Goukh, A. A. and Abu - Sarra, A.F.(1993).Compositional change during mango fruit ripening University of Khartoum Journal of Agricultural Sciences, 1(1),33-51.

[2] Ahmed, O.K. and Tingwa, P.O. (1995).Effect of gibberellic acid on severalparameters of ripening of 
banana fruit. University of Khartoum Journal of Agricultural Sciences, 3(1): 47 - 59.

[3] Ali, D. O. M., Ahmed, A. R. and Babiker, E. B. (2014). Suitability of Local Sudanese Guava (Psidiumguajava L.) Cultivars for concentrates production. Journal of Agri-Food and Applied Sciences, 2(8): 225 - 229.

[4] Al-Jabr, A. M. (2006). Toxicity and Repellency of Seven Plant Essential Oils to Oryzaephilussurinamensis (Coleoptera: Silvanidae) and Triboliumcastaneum (Coleoptera: Tenebrioidae). Scientific Journal of King Faisal University (Basic and Applied Sciences), 7 (1): 49 60.

[5] Al-Sarar, A. S., Husseini, H. I., Abobakr, Y., Bayoumi, A. E. and Al-Otaibi, M. T. (2014). Fumigant toxicity and antiacetyl cholinesterase activity of Saudi Menthalongifolia and Lavanduladentata species against Callosobruchusmaculatus (F.) (Coleoptera: Bruchidae). Türk. entomol. derg., 2014, 38 (1): 11 18.

[6] AOAC (2002). Official methods of analysis. $16^{\text {th }}$ edn, Association of Official Analytical Chemists, Washington DC.

[7] Baghel, B. S., Gupta, N., Khare, A. and Tiwari, R. (2005). Effect of different doses of gamma radiation on shelf - life of guava. Indian $J$ Hort, 62:129-132.

[8] Baka, M., Mercier, J., Corcuff, R., Castaigne, F., \& Arul, J. (1999). Photochemical treatment to improve storability of fresh strawberries. Journal of Food Science, 64, 1068-1072.

[9] Bashir, H. A. and Abu - Goukh, A.A. (2003). Compositional changes during guava fruit ripening. Food Chemistry, 80(4), 557 -563.

[10] Bateman, M. A. (1982). Chemical methods for suppression or eradication of fruit fly populations.In: Drew, R. A. I.; G. H. S. Hooper, and M. A. Bateman, Economic fruitflies of the South Pacific Region, 2nd edition, 115-128. Queensland Department of Primary Industries, Brisbane, Australia.

[11] Bedri, M. F. (1978). Evaluation of guava cultivars for processing as slices and fractionation and characterization of guava pectic substances. M. Sc. Thesis, U. of K., Khartoum, Sudan.

[12] Bisen, A. and Pandey, S. K. (2008). Effect of postharvest treatment onbiochemical composition and organoleptic quality in kagzi lime fruits during storage. J Hort Sci 3:53-56.

[13] Bintsis, T., Litopoulou-Tzanetaki, E., \& Robinson, R. K. (2000). Existing and potential applications of ultraviolet light in the food industry-A critical review. Journal of the Science of Food and Agriculture, 80, 637-645.

[14]Bosly, A. H. (2013). Evaluation of insecticidal activities of Menthapiperitaand Lavandulaangustifolia essential oils against house fly, Muscadomestica L. (Diptera: Muscidae). 5 (4): $50-54$.

[15]Bushara, A. M. M., Mustafa, A. A., Abdelhakam, K. E.K., Elfaki, H. A. and Eibaid A. I. A. (2016). Effect of adding guava fruit powder on the chemical and mineral composition of wheat flour. Journal of Academia and Industrial Research (JAIR), 4, 9: 203 $-205$.

[16]Chahal, S. and Bal, J. S. (2003). Effect of postharvest treatments and packaging on shelf -life of Umran ber at cool temperature. J Res Punjab Agric Univ, 40:363-99.

[17] Chandra, R. (1995). Biochemical changes during maturity and storage inguava fruits. Indian Hill Farming, 8:16-21.

[18]Das, R. M. and Medhi, G. (1996). Physico chemical changes of pineapple fruits under certain postharvest treatment. South Indian Hort, 44:5-7

[19]Dashora, L. K., Meena, M. C.and Mohammed, S. (1999). Effect of edible oil emulsion on post harvest shelf -life of ber (Ziziphus mauritiana,Lamk) cv. Umran. Adv Hort Forestry, 17:220-225.

[20] De Abreu, J. R., Dos Santos, C. D., De Abreu, C. M. P. and De Castro, E. M. (2012). Histochemistry and morphoanatomy study on guava fruit during ripening. Food science and technology (Campinas), 23 (1): $179-186$.

[21]Desai, B. B. and Deshpande, P. B. (1978). Chemical control of ripening in banana. Physiol. Plant, 44(3): 38 - 40.

[22] Dhaka, R. S., Verma, M. K. and Agarwal, M. K. (2001). Effect of post-harvesttreatment on physico -chemical characters during storage of mango cv. Totapari. Haryana J Hort Sci 30:36-38.

[23] Dhemre, J. K. and Waskar, D. P. (2003). Effect of postharvest treatments on shelf - life and quality of mango in evaporative cool chamber and ambient conditions. J Food Sci Technol, 40:316-318.

[24]Faruki, S. I., Das, D. R., Khan, A. R. and Khatum, M. (2007). Effects of Ultraviolet (254nm) Irradiation on Egg Hatching and Adult Emergence of the Flour Beetles, Tribolium castaneum, $T$. confusum and the Almond Moth, Cadra cautella. Journal of Insect Science 7(36): 1-6. 2007 
[25] Gomez, K. A. and Gomez, A. A. (1984). Statistical Procedures for Agricultural Research. pp. 75 - 165. $2^{\text {nd }}$ edition. John Wiley and Inc. New York, USA.

[26] González-Aguilar, G. A., Zavaleta-Gatica, R., \& Tiznado-Hernández, M.E. (2007).

[27] Improving postharvest quality of mango Haden by UVC treatment. Postharvest Biologyand Technology, 45, 108-116.

[28]Hori, M., Shibuya, K., Sato, M. and Saito, Y. (2014). Lethal effects of short-wavelength visible light on insects. Scientific reports, 4: 7383.

[29] Hulme, A.C.(1970). The biochemistry of fruits and their products. Innovative Food Science \& Emerging Technologies, 9: 348-354.

[30] Jagadeesh SL, Rokhade TS, Lingaraj U (2001). Infl uence of postharvesttreatments on storage behaviour of guava fruits cv.Sardar. J Maharashtra Agric Univ, 26:297-300.

[31] Kabbashi, E. B. M., Nasr, O. E., Musa, S. K.and Roshdi, M. A. (2012). Use of gamma irradiation for disinfestation of guava fruits from fruit flies [Ceratitis spp. \&Bactrocera sp. (Diptera: Tephritidae)]in Khartoum State, Sudan. Agricultural Science Research Journal, 2(4): 177 182.

[32] Kabbshi, E. B. M. (2014). Fruit insect pests of guava (Psidiumguajava L.) and their management in Sudan: A Historic review, US Open Food Science \& Technology Journal, 1 (3): 1 - 11.

[33] Karamaouna, F., Kimbaris, A., Michaelakis, A., Parachristos, D., Polissiou, M., Papatsakona, P. and Tsora, E. (2013). Insecticidal activity of plant essential oils against the vine mealybug [Planococcusficus (Signoret)]. J insect sci., 13: 142.

[34] Keyser, M., Müller, I. A., Cilliers, F. P., Nel,W., \& Gouws, P. A. (2008).Ultraviolet radiation as a nonthermal treatment for the inactivation of microorganisms in fruit juice. Innovative Food Science \& Emerging Technologies, 9, 348-354.

[35] Koutchma, T., Keller, S., Chirtel, S., \& Parisi, B. (2004). Ultravioletdis infection of juice products in laminar and turbulent flow reactors. Innovative Food Science \& Emerging Technologies, 5, 179189.

[36] Kumar, P., Mishra, S., Malik, A. and Satya, S. (2010). Insecticidal properties of Mentha species: A review. Industrial Crops and Products.34:802-817.

[37] Kumar, P., Mishra S, Malik A, Satya S. (2011). Repellent, larvicidal and pupicidal properties of essential oils and their formulations against the housefly, Muscadomestica L.Medical and Veterinary Entomology, 25: 302 - 310.
[38] Kumar, A. (2012). Importance for life (Psidium guava). International Journal of research in pharmaceutical and biomedical sciences, 3(1): 137 $-143$.

[39] Lin, D. and Zhao, Y. (2007). Innovations in the development and application of edible coatings for fresh and minimally processed fruits and vegetables. Comprehensive reviews in food science and food safety, 6(3): $60-75$.

[40]López-Rubira, V., Conesa, A., Allende, A., \& Artés, F. (2005). Shelf lifeand overall quality of minimally processed pomegranate arils modified atmosphere packaged and treated with UV-C. Postharvest Biology and Technology, 37, 174-185.

[41] Mahajan, B. V., Dhatt, A. S. and Sandhu, K. S. (2005). Effect of different postharvest treatment on the storage life of kinnow. Haryana J Hort, 20:156160.

[42] Mahmoud A.; Khidir, M. O; Khalifa, M. A.; El Ahmadi, A. B.; Musnad, H. A. and Mohamed, E. I. (1996). "Sudan: Country report to the FAO international technical conference on plant genetic resources". A Paper presented at the FAO international technical conference on plant genetic resources Leipzig, Germany, June $17-23$.

[43] Mahmoud, H. H. and Peter, T. S. (2014). Physical screening in fruits of guava (Psidiumguajava L.) genotypes. Journal of emerging trends in engineering and applied sciences, 5(2): $135-144$.

[44] Michaelakis A, Papachristos D, Kimbaris D, Polissiou M. (2012). Larvicidal evaluation of three Mentha species essential oils and their isolated major components against the West Nile virus mosquito. Hellenic Plant Protection Journal, 4:35-48.

[45] Mkaddem, M., Bouajila, J., Ennajar, M., Lebrihi, A., Mathieu, F. and Romdhane, M. (2009). Chemical composition and antimicrobial and antioxidant activities of Mentha (lonifolia L. and viridis L.) essential oils. J. food Sci, 74: 358 - 363.

[46] Nwaichi, E. O., Chuku, L. C. and Oyibo, N. J. (2015). Profile of Ascorbic Acid, Beta-Carotene and Lycopene in Guava, Tomatoes, Honey and Red Wine. Int. J. Curr. Microbiol. App. Sci, 4(2): 39 43.

[47]Pathak, R. K. Singh, G. Kishun, R. and Chandra, R. (2007). Improvement of guava (Psidiumguajava L.), throughbreeding, 85(1): 7567 - 7572.

[48] Rajendran S, Sriranjini V. (2008). Plant products as fumigants for stored-product insect control. Journal of Stored Product Research. 44:126-135.

[49]Rastegar, F., Moharramipour, S., Shojai, M. and Abbasipou, H. (2009). Toxicity of the essential oil 
of Salviaofficinalis L. on Triboliumcastaneum (Herbst). Arab Journal of Plant Protection, 27: 123 -124 .

[50] Renkema, J. M., Wright, D., Buiterhuis, R. and Hallett, R. H. (2016). Plant essential oils and potassium metabisulfite as repellents for Drosophila suzukii (Dipter: Drosophilidae). Sci Rep., 6: 21432.

[51] Roessler, Y. (1989). Insecticidal bait and cover sprays. In: Robinson, A. S. and Hooper, G. (eds), Fruit flies, their biology, natural enemies and control, vol. 3B. Elsevier Science Publishers, Amsterdam, Pp. 329 - 335.

[52] Singh, U. B. and Shaffat, M. (1997). Comparative efficacy of waxemulsion and rice starch on postharvest shelf -life of fully ripe guava fruits. $J$ Food Sci Technol 34:519-522.

[53] Stark, W. S., Walker, K. D. and Eidel, J. M. (1985). Ultraviolet and blue light induced damage to the Drosophila retina: Microspectrophotometry and electrophysiology. Current Eye Research, 4(10): $1059-75$.

[54] Stevens, C., Khan, V. A., Wilson, C. L., Lu, J. Y., Chalutz, E., \& Droby, S. (2004). The effect of fruit orientation of postharvest commodities following low dose UVC treatment on host induced resistance to decay. Crop Protection, 24, 756 - 759.

[55] Thomas S.A., Molina E.-B., Stolik S., Sanchez F. (2005). Composite oil coating preserves the quality of pineapple fruits. J Physiq IV France, 125:889892.

[56] Viera, S. M., Gomez, P., Benedetti, B. C. and Artès, F. (2009). UVC radiation effect on the mortality of fruit fly eggs. CIGR Proceedings, Technology and management to increase the efficiency in sustainable agricultural systems, Rosario, Argentina, 2009.

[57] Waziri, M. andSalih, I. A.(2015). Proximate Analysis and Phytochemical Screening of Psidiumguajava (Guava) and Cucumissativus (Cucumber) Grown in Gashua Fadama Area of Yobe State, Nigeria. International Research Journal of Pure and Applied Chemistry, 6 (2): $77-83$.

[58] Wills, R. H.H., Lee, T.H., Graham, D., McGlsson, W.B. \& Hall F.G.(1981). Postharvest: an introduction to the physiology and handling of fruits and vegetables. Westport, Connecticut: AVE publ.Co.

[59] Wood, M. (2000). "For males only. Temperature sensitive Medflies." Agricultural Research Magazine. United States Department of Agriculture, Washington, D. C.
[60] EI-Monem, E. A., Mostafa, A., EI-Mageed, M. A. A. (2003). Effect of some postharvest treatments on the storage quality of Annona and on its volatile components. Annols Agri Sci Cario;48(2):757-775. 